\title{
XIV ISCM, Hangzhou, China, May 2013: Opening Remarks
}

\author{
Alexander G. Karczmar
}

Published online: 13 November 2013

(C) Springer Science+Business Media New York 2013

Keywords Cholinergic · Acetylcholine - Self-behaviors · Amotions

I am honored to present these opening remarks at the XIV International Symposium on Cholinergic Mechanisms (ISCM) in Hangzhou and to greet so many of my old friends - even though in absentia. My old late friend, Carlos Chagas, Jr., remarked once that the major reward of an assiduous scientist - an ancient cholinergiker in my caseis that he becomes able to form dear friendships all over the world, and I cherish immensely having achieved this status. Spiritually, if not bodily, I greet warmly all of my many friends, present here in the beautiful garden city of Hangzhou! And I regret that the two of my best friends, JeanPierrre Changeux and Victor Whittaker, could not take part in this ISCM.

Forty-three years evolved since the late Edith Heilbronn organized in Skokloster, Sweden, the first ISCM (this term was first employed at Don Jenden's third ISCM, held in La Jolla, CA). This is a long time of existence for a scientific organization, but this time dwarfs almost to nothingness in comparison with the first written statement concerning the existence of cholinergic toxins and

A. G. Karczmar $(\bowtie)$

Department of Pharmacology, Loyola U. Med. Center,

Maywood, IL, USA

e-mail: alexkarczmar@gmail.com

\section{A. G. Karczmar}

Edward Hines, Jr. VA Hospital, Hines, IL, USA

A. G. Karczmar

1830 North Lincoln Ave, Chicago, IL, USA hallucinogens in Mesopotamia and in the Roman Empire (see Karczmar 2007, 2010, Karczmar: "The Unknown 'I'", unpublished). This long tenure of cholinergicity makes it appropriate to hold this XIV ISCM in China, a country of timeless civilization and ancient science. This status was described by Sir Joseph Needham, a British neurochemist and historian, in an opus of many volumes which was continued by his successors till it reached the status of 20 volumes (Needham 1943, 1961) (see Figs. 1 and 2). Sir Joseph worked on his masterwork in China, where he was

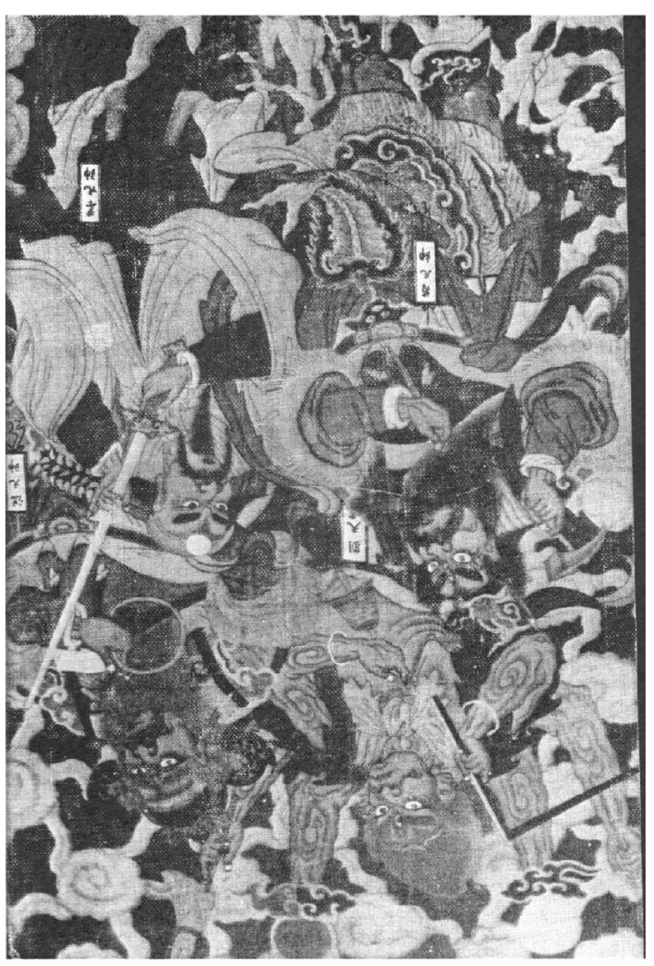

Fig. 1 Book cover, Needham (1961). An ancient Chinese tapestry 
Fig. 2 Frontispiece, vol. 1, Needham (1961)

\section{SGIENGE AND \\ GIVILISATION IN \\ CH INA \\ BY \\ JOSEPH NEEDHAM F.R.s. \\ S1R WILLIAM DUNN RBADER IN BIOCHRMISTRY IN THE \\ UNIVIRETTY OP CAMBRIDOR, FRLLOW OF OONVILLE AND CATES COLLBOE \\ POREICN MEMBER OP ACADBMIA SINICA \\ With the research assistance of \\ WANG LING \\ ACADEMIA SINICA AND \\ TRINITY COLLEOK, CAMBRIDGE \\ $<$ \\ VOLUME 1 \\ INTRODUCTORY \\ ORIENTATIONS

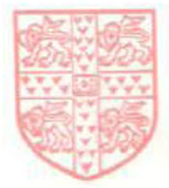 \\ CAMBRIDGE \\ AT THE UNIVERSITY PRESS \\ $196 \mathrm{I}$}

cited in schools and universities and where he became popularly and fondly referred to as Li Yuh-Se.

Now, let me illustrate the scientific importance and the wide range of the topics of the ISCMs. Table 1 shows the sites, the hosts, and the published proceedings of the 13 previous ISCMs. The table emphasizes the global reach of the ISCMs and the prominence of their hosts. The Nobelist Ulf von Euler introduced the first ISCM in Skokloster, and our good friend Ezio Giacobini, present here today, played a major role in
Skokloster as a molecular cholinergiker rather than a clinical expert who, together with Peter Waser, George Koelle, Don Jenden, Victor Whittaker, Giancarlo Pepeu, and Eduardo de Robertis, was among the participants of the last few ISCMs and of this Symposium.

The first ISCM boasted a wide range of topics, from cholinergic receptors to anticholinesterases and to acetylcholine metabolism, a characteristic of all subsequent ISCMs which always presented the up-to-date overview of total cholinergicity as well as its continuous progress. 
Table 1 From Skokloster, 1970 to Hangzhou, 2013: the 14 ISCMs

The First ISCM, Skokloster, Sweden, 1970

"Drugs and Cholinergic Mechanisms in the CNS"

Hosts and Editors: Edith Heilbronn and Anders Winter

Forsvarets forskningsinstitutt, Stockholm, 1970

The Second ISCM, Boldern, Switzerland, 1974

"Cholinergic Influences on Behavior"

Host and Editor: Peter G. Waser

Raven Press, New York, 1975

The Third ISCM, La Jolla, California, 1977

"Cholinergic Mechanisms and Psychopharmacology"

Host and Editor: Don Jenden

Plenum Press, New York, 1978

The Fourth ISCM, Florence, Italy, 1980

"Cholinergic Mechanisms"

Hosts and Editors: Giancarlo Pepeu and Herbert Ladinsky

Plenum Press, New York, 1981

The Fifth ISCM, Oglebay Park, PA, USA, 1983

"Dynamics of Cholinergic Function"

Host and Editor: Israel Hanin

Plenum Press, New York, 1984

The Sixth ISCM, Buxton, England, 1986

"Cellular and Molecular Basis for Cholinergic Function"

Hosts and Editors: M. J. Dowdall and J. M. Hawthorne

The Seventh ISCM, Stockholm, Sweden, 1989

"Cholinergic Basis for Function and Clinical Application"

Hosts and Editors: Sten Magnus Aquilonius and Per-Goran Gillberg

Elsevier, Amsterdam, 1990

The Eighth ISCM, Sainte-Adèle, Quebec, 1992

"Cholinergic function and Dysfunction"

Host and Editor: A. Claudio Cuello

Elsevier, Amsterdam, 1993

The Ninth ISCM, Mainz, Germany, 1995

"Cholinergic Mechanisms: From Molecular Biology to Clinical Significance"

Hosts and Editors: Jochen Klein and Konrad Loffelholz

Elsevier, Amsterdam, 1996

The Tenth ISCM, Arcachon, France, 1988

"From Torpedo Electric Organ to Human Brain"

Host and Editor: Jean Massoulie

Elsevier, Paris

The Eleventh ISCM, St. Moritz, Switzerland, 2002

"Cholinergic Mechanisms"
Table 1 (continued)

Hosts and Editors: Israel Silman, Hermona Soreq, Lili Anglister,

Daniel Michaelson, and Abraham Fisher

Taylor and Francis, London, 2004

The Twelfth ISCM, Alicante, Spain, 2005

"The Twelfth International Symposium on Cholinergic Mechanisms"

Host and Editor: Jose M. Gonzlez-Ros

Journal of Molecular Neuroscience, vol. 30, 2006

The Thirteenth ISCM, Foz do Iguacu, Brazil, 2008

"Neuronal and Non-Neuronal Cholinergic Systems: Molecular and Translational Significance"

President: Edson X. Albuquerque; Vice-President: Rosely O. Godinho Editors: Edson X. Albuquerque and Rosely O. Godinho

Journal of Molecular Neuroscience, vol. 40, 2010

Thus, there was a continuous advancement of the receptor lore, ranging from the structure-activity relationship (SAR)-based presentation of the cholinergic receptors to the molecular and allosteric exposition of the muscarinic and nicotinic receptors. Then, there was, in the course of the ISCMs, a gradual addition to micromolecular events of the macromolecular cholinergic phenomena, including cholinergically related behaviors such as learning and addiction, toxic phenomena, neuromyal function, sleep, and stress. And then, at the XII ISCM hosted in Alicante by Jose Gonzalez-Ros, there was the first presentation of neuroscientific characteristics of the "self" and of their possible linkage with quantal phenomena, a subject to be continued at this Symposium in the course of its Section 9. And the cholinergicity of emotions is presented for the very first time at this Symposium!

To give an example of this progress, I will first show the SAR scheme of the nicotinic receptor presented by Ric Belleau at the first ISCM (Fig. 3). This linear, simplistic presentation is replaced today by three-dimensional mobile pictures of the nicotinic receptors, showing specific proteins and their position about the receptor channel; these pictures and their allosteric properties were elaborated particularly by Jean-Pierre Changeux. Altogether, the ISCMs fully represent the progress of cholinergic lore, and each ISCM shows the full scope of the current state of cholinergicity.

Edith Heilbronn convened a cholinergic symposium as she felt the need for such a meeting, since in the 1970s, there was a plentitude of meetings and symposia concerning catecholamines, GABA, etc., but there were no cholinergic meetings. The situation is not very much changed at this time. True, we have meetings on cholinesterases, now numbering 11 gatherings, but still there are no meetings, except the ISCMs, that would embrace the total subject of cholinergicity. For example, at the Symposia of The American College of Neuropsychopharmacology, the cholinergic system is barely 
Fig. 3 Belleau's SAR-based linear presentation of the surface of the nicotinic receptor, as presented at the 1970 first ISCM, Skokloster, p. 246. DPA a piperidine derivative, $\mathrm{C} 10$ decamethonium. Other titles are spelled out in the figure
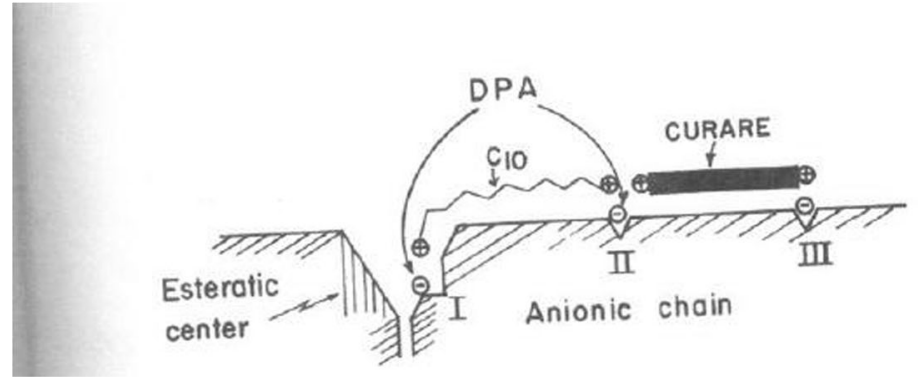

mentioned. Altogether, by now, the ISCMs are considered as quasi official representations of the status of the cholinergic field at the time of any given ISCM. And the XIV ISCM in Hangzhou is a worthy descendant of the previous ISCMs, as the speakers at this Symposium will present the enormous advances made in the areas of receptology, structural characteristics of several cholinesterases, modulatory and allosteric phenomena, multiple acetylcholine release mechanisms, toxic phenomena linked with cholinesterase inhibitors, new neuromyal phenomena, clinical aspects of the cholinergic field, and cognitive and addictive behaviors, emotions, and the self. We owe much gratitude to Karl Tsim and his Local Organizing Committee for preparing for us such a feast of cholinergicity and locating this feast in the beautiful and historical Hangzhou; personally, I thank warmly Karl and Dr. Ava Guo for the help and friendship that they afforded to me.

No less significantly, we will pay a tribute at this Symposium to those great cholinergikers who passed recently away, Jean Massoulie, Elsa Reiner, and Itzchak Parnas; Larry Butcher is also gone, but this sad event occurred too recently to prepare a tribute to him. As long as cholinergicity is discussed and lauded, they will not be forgotten!
Finally, I am sure that an exponential progress of many areas of cholinergicity will occur in the course of future ISCMs, including the use of NMR imaging for subtle localizing of cholinergic elements and metabolism; studies of emotions; quantal-and who knows, "string" and "M-theory"aspects of cholinergicity; in the quest for cholinergic correlates of the self; and with regard to the solution of the body-mind dilemma. Cholinergicity will not be like a Roman Empire that rose rapidly to fall as fast; rather, cholinergicity is like the mighty Himalayas that rise and continue to grow!

\section{References}

Karczmar AG (2007) Exploring the vertebrate central cholinergic system. Springer, New York

Karczmar AG (2010) Do all human functions and behaviors, as well as the "self", have cholinergic correlates? J Molec Neurosci 40:121-126

Needham J (1943) Science and Civilization in China, vol 1. Cambridge University Press, Cambridge

Needham J (1961) History of scientific thought. In: Science and civilization in China, vol 2. Cambridge University Press, Cambridge 